\section{Bibliography of Soviet Science}

A BIBLIOGraphy to provide research workers, librarians and students with basic information on Soviet scientific and technical activity has been completed with the aid of a National Science Foundation grant. Entitled Soviet Science and Technology: A Bibliography on the State of the Art, 1955-1961, and available for 1 dollar each from the Superintendent of Documents, Govermment Printing Office, Washington 25, D.C., the 209-page compilation contains about 2,000 annotated entries for periodic and monographic materials from Soviet bloc and Western sources published for the most part between 1955 and 1961 . References fall into four main categories: surveys, bibliographies, reports of visits to Soviet scientific and industrial institutions, and articles deemed to show significant Soviet progress in particular fields. Entries are arranged alphabetically by author or first word of title under approximately 100 subject headings. Titles in languages of the Soviet bloc have been translated while those in Western languages have not.

\section{The 'Pisto Laser'}

Tue first practical research tool based on solid state lasers to be made available in the United Kingdom is announced by Kollsman Instrument, Ltd. The 'Pisto Laser', so called because of its double pistol-grip triggering, was designed and developed by the Company's associate in the United States of America, the Kollsman Instrument Corporation. It emits a beam of intense, coherent red light of wavelength $6929 \AA$., with a beam divergence of less than 0.3 degree. The duration of the light pulse train is approximately $0.2 \mathrm{msec}$. and it has an extremely low threshold of 90 joules. The radiation output of the pulsed, ruby, laser beam is more than $10^{9}$ times the corresponding output of the Sun within the same frequency band. 'The 'Pisto Laser' is designed to operate either automatically or manually and is equipped with a continuously variable high-voltage power supply. Its miniaturized size makes it highly portable and it may be operated by battery or conventional alternating current supply. The dual safety trigger control prevents accidental firing. Accessory units are available to supplement the 'Pisto Laser' light source in order to demonstrate particular advanced optical electronic systems, for example, optical radar. In communications research the 'Pisto Laser' can be used to study the characteristics of very narrow beam-width transmission of optical data; in medical research, high-intensity cauterization; in crystallography, crystal structures using non-linear light transmission; in photography, pictures of extreme clarity; and in biology, biological responses to high-intensity monochromatic stimulation.

\section{The British Internal Combustion Engine Research Association}

Ar the annual general meeting of the British Internal Combustion Engine Research Association, Prof. S. J. Davies was elected prosidont in succession to the late Viscount Falmouth. Prof. Davies, formerly professor of mechanical engineering at King's College, University of London, and shortly to retire from being dean of the Royal Military Colloge of Science, has been a vice-president of the Association since 1960. Re-elected as vice-presidents were: Brigadier J. R. G. Finch, director, Royal Engineer Equipment, War Offico; Rear-Admiral R. S. Hawkins, director of Marine Engineering, Admiralty; H. N. Pemberton, chief engineer surveyor, Lloyd's Register of Shipping. The new chairman of Council is S. J. Wood, manager of the Diesel Engine Department of W. H. Allen, Sons and Co., Ltd. The new vice-chairman is Dr. J. A. Pope, research director of Mirrlees-National Research Division. Newly-elected members of Council are C. J. Hind (Ruston and Hornsby, Ltd.) and V. H. Hopkins (Diesel Engine Division, English Electric Co., Ltd.). The Council also includes F. A. Blackith (Wellworthy, Ltd.); W. H. Lindsey (Bristol Siddeley Engines, Ltd.); and J. G. Dawson (F. Perkins, Ltd.), who has been co-opted as immediate pastchairman. G. A. McMillan represents the Department of Scientific and Industrial Research on the Council.

\section{Announcements}

We regret to announce the untimely death on July 15 of Mr. M. Minton, who was employed by the Derritron Group of Companies as their senior technical representative. Mr. Minton was universally known for his work in the vibration field, his advice often being sought and his opinions respected.

A congress on "The Special Use of Vacuum Techniques", arranged by the Deutsche Gesellschaft für Vakuumtechnik, will be held in Frankfurt am Main during Soptomber 18-21. Further information can be obtained from the Deutsche Gesellschaft für Vakuumtechnik, Georg-Speyer-Strasse 83, Frankfurt (Main) W. 13.

THE first British congress on "The History of Pharmacy", organized by the Faculty of the History of Medicine and Pharmacy of the Society of Apothecaries with the co-operation of the Pharmaceutical Society, and sponsored by Boots, Ltd., will be held at the University of Nottingham during September 22-25. Further information can be obtained from Dr. F. N. L. Poynter, Wellcome Historical Medical Library, the Wellcome Building, Euston Road, London, N.W.1.

A COURSE on "Biochemistry and Biophysies in Food Research", jointly sponsored by the Low Temperature Research Station, Cambridge, and the Department of Food Science, Royal College of Science and Technology, Glasgow, will be held in Cambridge during September 23-29. Further information and forms of application can be obtained from the Director, Low Temperature Research Station, Downing Street, Cambridge.

Tre autumn meeting of the Institute of Metals will be held in Swansea during September 24-28. The programme will include the following sessions: tests for deep drawing; strength of fibrous materials; creep; zirconium alloys; embrittlement of copper. The Metallurgical Enginering Lecture, entitled "Survey of Some of the New Metals available to the Engineer", will be given by Dr. N. P. Inglis. Further information can be obtained from the Secretary, Institute of Motals, 17 Belgrave Square, London, S.W.1.

A Jornt meeting of the German Society of Physiological Chemistry and the Austrian Biochemical Society will be held in the Univorsity of Vienne during September 26-29. The twenty-seventh annual meoting of the German Pharmacological Society will be held in Vienna at the same time. Further information can be obtained from Dr. K. H. Spitzy, Officer for the Secretariat, Wiener Medizinische Akademie für Arztliche Fortbildung, Alserstrasse 4, Vienna. 